\title{
Geomorphological analysis of Tinto-B Vallis on Mars
}

\author{
Vilmos STEINMANN ${ }^{1,2}$, Áкоs KERESZTURI² and LÁszLó MARI ${ }^{1}$
}

\begin{abstract}
This work analysis an $81 \mathrm{~km}$ long $1.85 \mathrm{~km}$ wide fluvial valley on Mars (at $2^{\circ} 55^{\prime}$ South and $111^{\circ} 53^{\prime}$ East) for the first time, located near to the so-called Palos carter and Tinto Vallis, called Tinto-B hereafter. The length of the valley is approximately $81 \mathrm{~km}$, and the average width is $\sim 1.85 \mathrm{~km}$, depth $\sim 250 \mathrm{~m}$. The hypsometric curves were created in 5 different buffer sizes on the main valley and the biggest tributary valley. The tributary valley shows a youth stage in the geomorphological evolution opposite to the main valley, which shows a mature stage. The crater statistical analysis based age of the main valley $(2.9 \mathrm{Ga})$ poorly correlates with the early wet period of the red planet, thus, formed somehow later than most Martian valleys. Using the model SIMWE (SIMulated Water Erosion), for the to identify the small-scaled tributary valley systems and the small-scaled erosional landforms showed area elevated drainage density. The highest density of the tributary sections is $29.02 \mathrm{~km} / \mathrm{km}^{2}$, and the average is $3.09 \mathrm{~km} / \mathrm{km}^{2}$. Considering only the main valley $0.017 \mathrm{~km} / \mathrm{km}^{2}$ would have been measured, suggesting dozen(s) early tributaries were heavily eroded.
\end{abstract}

Keywords: Mars, erosion, SIMWE, fluvial erosion, morphology

Received March 2020; Accepted October 2020.

\section{Introduction}

Valley networks on the Mars has been attributed dominantly to surface run-off (CRADDock, R.A. and HowARD, A.D. 2002; IRwIN, R.P. and HowARD, A.D. 2002), groundwater sapping (CARR, M.H. 1981; CARR, M.H. and Malin, M.C. 2000; Goldspiel, J.M. and Squyres, S.W. 2000; Grant, J.A. 2000) or a combination of runoff and sapping (first suggested by Milton, D.J. 1973). Even so, the Martian fluvial valleys (BAKER, V.R. 1988; BAKER, V.R. et al. 1992; Clifford, S.M. 1993; Dohm, J.M. et al. 2015; Hargitai, H.I. et al. 2019; VAz, D.A. et al. 2020) show many similarities with the terrestrial fluvial system especially with the dry or semi-dry valleys, desert wadi (Hauber, E. et al. 2009). Fluvial structures like terraces suggest multiple periods of formation (MANGOLD, N. et al. 2004), and the correlation with other fluvio-sedimentary features and chloride salts suggest extended activity periods on Mars (HyNEK, B.M. et al. 2010), while various terminal deposits (SAlese, F. et al. 2020) demonstrate mainly early fluvial transport on the planet. Most valley networks formed around the Noachian/Hesperian boundary about 3.7 Ga ago (Hynek, B.M. et al. 2010) or earlier, but there was valley formation in later episodes even during Amazonian ages (FAssetT, C.I. and HEAD, J.W. 2008) occasionally, although there are indications that suggest that the style of post-Noachian activity differs from the later type (HowARD, A.D. et al. 2005).

Although current conditions are not favourable for bulk phase liquid water on Mars (Möhlmann, D. and Kereszturi, A. 2010; Martín-Torres, F.J. et al. 2015; Horne, D.J. 2018; Schorghofer, N. et al. 2018) or might

\footnotetext{
${ }^{1}$ Eötvös Loránd University. 1117 Budapest, Pázmány Péter sétány 1/A. Hungary. E-mails: steinmann.vilmos@ csfk.mta.hu, malkact@caesar.elte.hu

${ }^{2}$ Konkoly Thege Miklós Astronomical Institute, Research Centre for Astronomy and Earth Sciences. 1121 Budapest, Konkoly Thege Miklós út 15-17. Hungary. E-mail: kereszturi.akos@csfk.mta.hu
} 
emerge as small ephemeral flows in gullies (Conway, S. et al. 2019; de HaAs, T. et al. 2019), and elevated humidity might produce microscopic liquid phase ephemerally (PAL, B. 2019), old fluvial systems are well preserved and abundant.

The analysed area is at the southern highlands, where many old fluvial systems are present (Palumbo, A.M. et al. 2020). It is situated near to Palos crater and Tinto Vallis (Figure 1), thus, the analysed Vallis was named Tinto-B. This area includes several smaller valleys, which are located West from Tinto-B Vallis (see later the western part in Figure 2 inset ' $a$ ').

The aims of this work are (1) to compare the target valleys with resemble other ones, (2) put the target valley to context regarding its formation age, and (3) identify and evaluate the potential eroded tributaries in the surroundings using the flow and erosional simulating SIMWE (SIMulated Water Erosion) model.

\section{Materials and methods}

Three methods were used to understand better the characteristics and formation of the target valley(s): (1) image and topography based morphological analysis, including the analysis of longitudinal and cross-sectional profiles; (2) exposure age estimation using crater size-frequency distributions at separated surface units; and (3) applied erosion model-based evaluation of surface features regarding formerly existed but heavily eroded tributaries.

Although this later model (SIMWE) has not been earlier applied to Mars before, as this is not suitable to do the calculations that are required to reconstruct the surface modifications perfectly yet, however, the identification of eroded tributaries, and provide the basis for future more detailed exploration of this modelling environment.

ESRI ArcMap 10.4.1 and GRASS GIS 7.6 were used for analysing the PDS/GIS data-

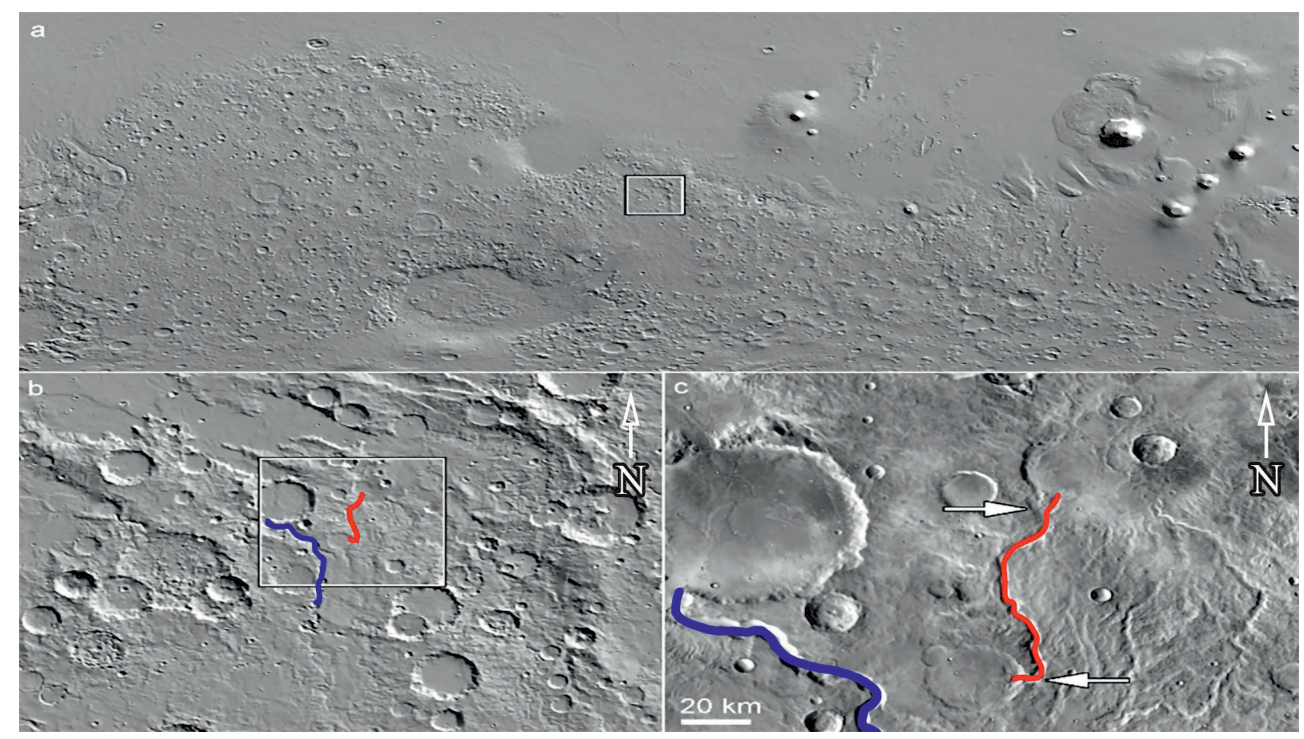

Fig. 1. Overview image from the analysed area, what is located at the southern highlands (a), close to the Tinto Vallis (b), lower left of the boxed area, while the target valley is at the centre. The target valley Tinto-B is visible in the ' $\mathrm{c}$ ' inset, with the starting and termination points are marked with arrows. The blue line represents the Tinto Vallis, the red line shows the analysed valley, Tinto-B on inset ' $b$ ' and ' $c$ '. Source image: MOLA (Mars Orbiter Laser Altimeter) shaded relief (NE) - JMARS (more detailed image, from the analysed valley on Fig. 7). 
sets. The original DTM (Digital Terrain Model) is a HRSC (High Resolution Stereo Camera - on board Mars Express mission - Neukum, G. et al. 2004) based map with 50m/px (metre/pixel) resolution h0951_0000_ dt4 (Sidiropoulos, P. and Muller, J. 2015) and the used CTX (Context Camera - on board Mars Reconnaissance mission) images with 5m/px resolution: P22_009796_1771_ XN_02S248W/P11_005511_1761_ XN_03S248W. The used coordinate system is the Martian Sinusoidal (projection-type: Sinusoidal, central meridian: 112). During the measurements, the errors from uncertainty in pixel pointing, in the database and in the georeferencing were less than 5 metres. The calculated values were used for statistical purposes.

The hydrological analysis was made in ArcMap with ArcHydroTools (used version: 10.2) to identify post fluvial eroded, thus, poorly visible ancient tributaries. In this research, the authors used the Fill tool to auto-fill the possible depressions on the used DTM and Flow Direction and Flow Accumulation tools to determine the gullies and flows on the analysed area (Figure 2). For crater identification the above-listed CTX image was used, where those features were counted as craters, which were at least 4-6 pixel diameter, showed an arc-shaped brighter and a darker features and they presented a circular shape together (minimum crater size: 20 metres).

As at this spatial scale, no boulders could be observed, and at the target area no noticeable crater-like erosional, mainly cryo karst pit depressions (Hargitai, H. and KereszTURI, A. 2015) were present, most craters could be firmly identified. Those surface structures were considered as impact craters, which showed a brighter than the surroundings solar facing arc-shaped area and a darker than the surroundings anti-solar facing
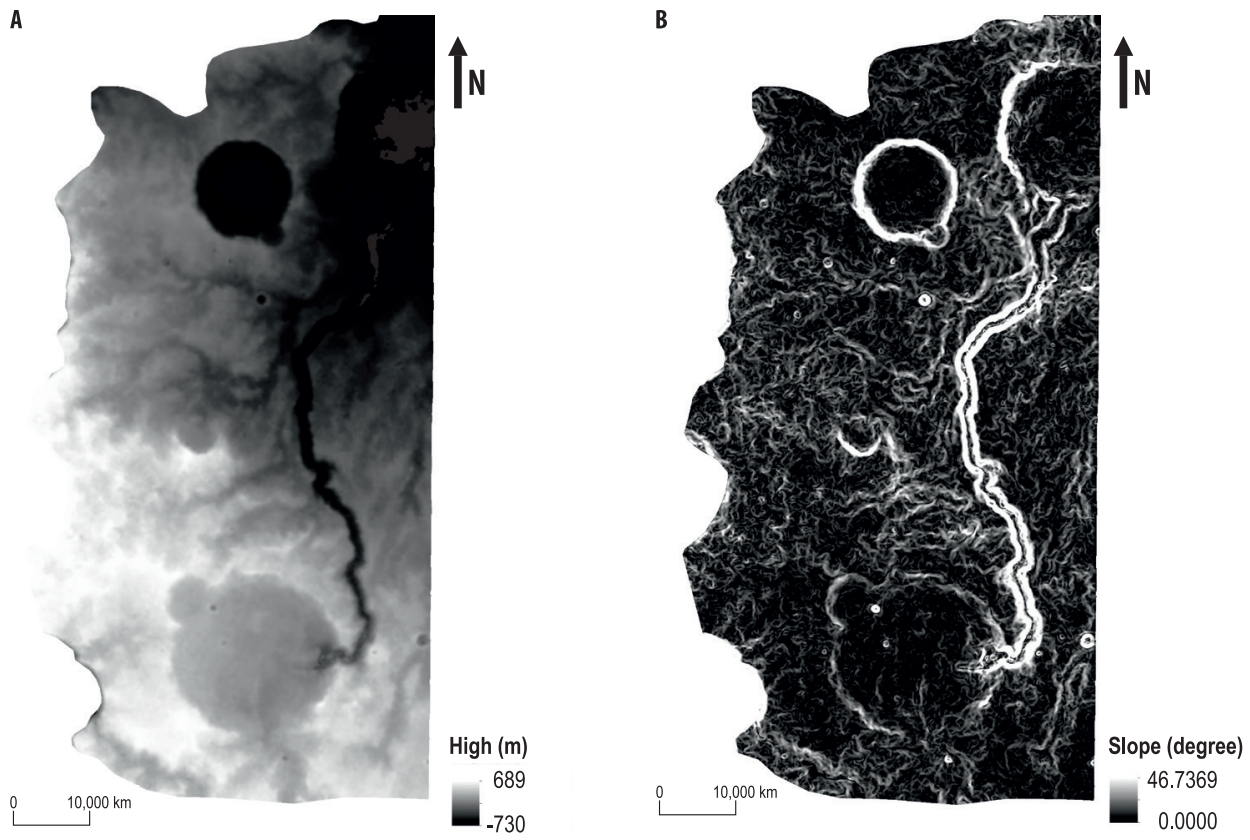

Fig. 2. The DTM (a) and the slope map (b) of the analysed area using HRSC topographic data. One of the steepest slopes (bright colour in the right inset) can be found along the main valley. 
arc-shaped area, and these two form a circular shape structure. For the age estimation, the authors used the CraterTools (KNEISsL, T. et al. 2011) and Craterstat (Michael, G. and Neukum, G. 2010) software. The age was estimated inside the selected area, characteristic to the given surface unit.

The drainage density was calculated from the former calculated flow accumulation maps in ArcMap with the Flow Accumulation tool. The length of the flows was measured in a $1 \times 1 \mathrm{~km}$ size grid map. The drainages represent the results of the flow accumulation, where the value was bigger, than 150 and converted to polyline features. These features' cumulative length were measured in each grid cell.

For the erosion simulation, the SIMWE (SIMulated Water Erosion) model (Mitasova, H. et al. 2004) was applied. The model uses the original elevation file and the $x$ and $y$ derivatives, which are generated with the script r.slope.aspect. The model uses a hypothetic water depth, which is calculated from the original elevation and a user-defined given a single storm event $(\mathrm{mm} / \mathrm{hr})$ in a certain time (min) with the script r.sim.water.

The erosion-deposition rate was calculated with the script r.sim.sediment, which uses several other components, like detachment and transport coefficient, shear stress and infiltration value. The model is under testing and was applied not to estimate specific numerical erosion or deposition rate but only to identify eroded, old tributary valley segments. The model in this study was used with a $15 \mathrm{~mm} / \mathrm{hr}$ rain event for 3 minutes. With this approach, more candidate valleys could be identified than based on a simple optical survey of images.

Two hypsographic curves were acquired from the main valley and the biggest tributary valley using five different buffer sizes. The central curve of the buffers is the longitudinal axis of the valley, the other also runs along the bottom of the valleys with width: $500,750,1,000,1,250$ and 1,500 $\mathrm{m}$. The buffers outlined were made in ArcMap, the final calculation in Ms Excel.

\section{Results}

The target valley has a main deep depression, with few short (2-4 km long) tributaries at its uppermost region, however, several uncertain, heavily eroded and moderately longer tributaries could be suspected along it. The length of the main valley is approximately $81 \mathrm{~km}$, and the average width is $\sim 1.85 \mathrm{~km}$, depth $\sim 250 \mathrm{~m}$. The highest point of the analysed area is $+689 \mathrm{~m}$ in local relief, and the deepest is -730 metres, the flow direction of the valley is from South to North.

The main characteristics of the valley were compared to the nearby Tinto Vallis (Figure 1 bottom left of ' $\mathrm{c}$ ', also located at Tyrrhena Terra), which has been previously analysed by other authors (RAuHALA, A.I. and Kostama, V.-P. 2012a). Tinto Vallis formed around 3.6-3.5 Ga probably by a catastrophic flooding event and poured its water to the $53 \mathrm{~km}$ diameter Palos crater, where the wall was breached out and produced an ever further outflow with about $300 \mathrm{~km}$ length to the north. Both fluvial and volcanic origins have been proposed for the Tinto Vallis, and formation first by stage groundwater flow (CARr, M.H. and Malin, M.C. 2000) and later by catastrophic outflow. Tinto Vallis gets gradually wider and deeper in downflow direction and presents sapping morphology with about 0.4 per cent average slope angle and width to depth ratio around 5. Its volume is about $266 \mathrm{~km}^{3}$, which seems to be able to lay down a $120 \mathrm{~m}$ thick sedimentary layer at the bottom of Palos crater (Rauhala, A.I. and Kostama, V.-P. 2012b).

The valley of Tinto-B is obvious in the CTX images, it has sharp and relatively steep walls, the sharp edge and its bottom could be firmly outlined (Figure 3, inset ' $\mathrm{f}$ '). The source area is a $22.5 \mathrm{~km}$ sized and $\sim 400 \mathrm{~m}$ deep crater with smooth, possibly infilled floor, where a moderately deep branching upper part of Tinto-B was cut into. The starting points of these tributaries are sharp and the valleys widen and deepen fast. Along most of the valley, its sides are steep enough to show partly smooth or downward 

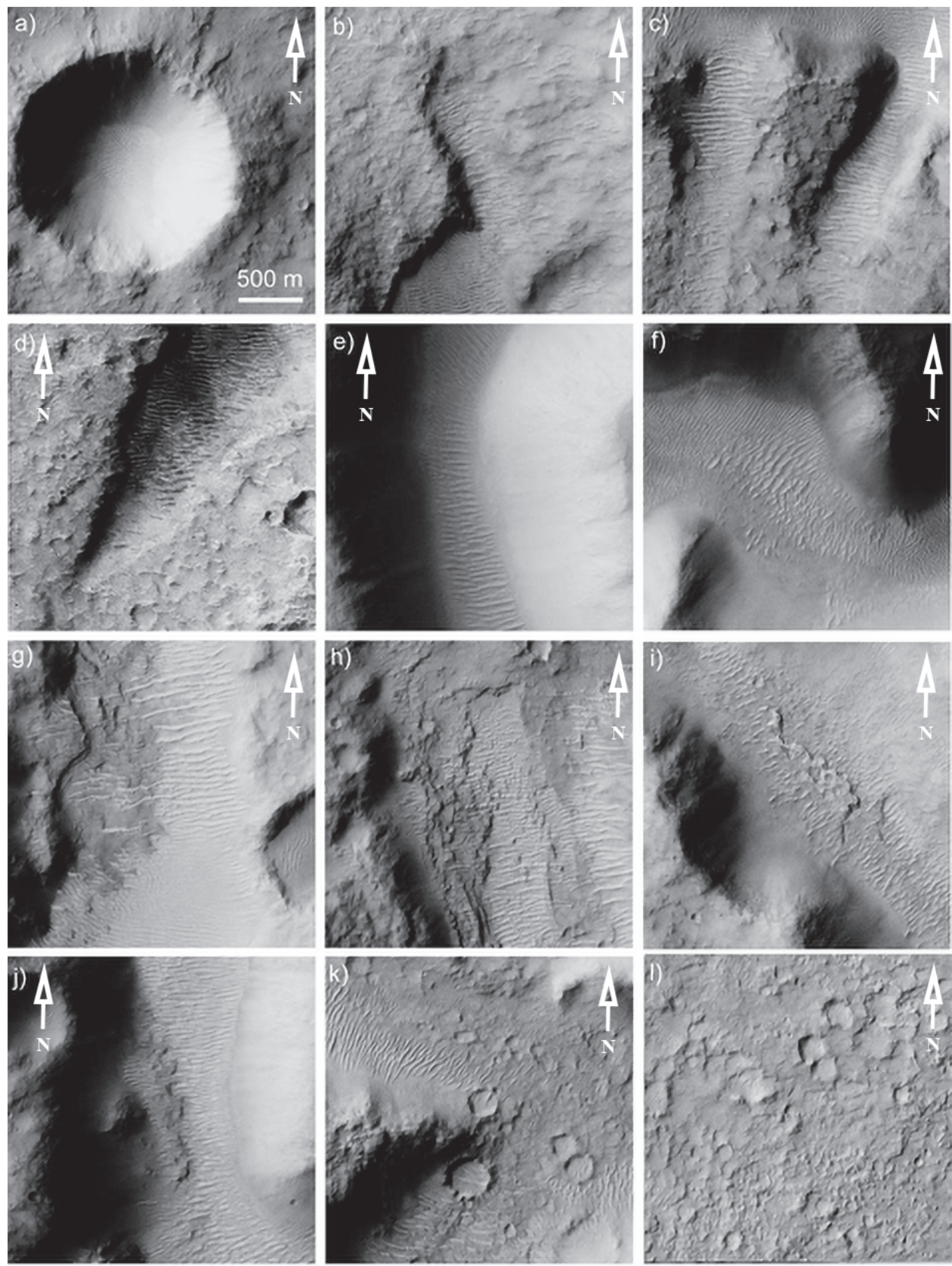

Fig. 3. $2 \times 2 \mathrm{~km}$ sized insets of the used CTX images are indicated, presenting examples for the following observed morphological features. The exact locations of the images are represented on Fig. 7. $-\mathrm{a}=$ crater at the surrounding old terrain; $\mathrm{b}, \mathrm{c}$ and $\mathrm{d}=$ small and sudden deepening tributaries at the source area; $\mathrm{e}=$ deep, typical section of the main valleys; $\mathrm{f}=$ sharp curvature of the main valley; $\mathrm{g}=$ system of transverse dunes at the bottom of the valley; $h, i$, and $j=$ part of the layered channel deposit outcrop; $k=$ entry mouth of the valley in the terminal crater; $1=$ bottom of the terminal crater 
striped morphology, suggesting mass movements happened there. At most of its bottom (valley floor), ripple mark patterned surface sand deposits are present. At a few locations $(\sim 8)$ the original, very old bedrock bottom outcrops are present at the central part of the valley (Figure 3, inset h, i and j). There are 13 such bedrock exposures on the mainly sand-covered valley bottom, located around the northern and southern parts of the valley. The total area of the bedrock exposures is $5,022,254 \mathrm{~m}^{2}$, the biggest one is $2,710,238$; the smallest is $27,393 \mathrm{~m}^{2}$.

The terminal sink structure is an $18.13 \mathrm{~km}$ diameter crater at north where no obvious depositional structure can be identified. The interior of the terminal sink crater is filled by some smooth sediment.

Five histogram profiles made on the main valley are visible in Figure 4 inset ' $a$ ' and the largest tributary in Figure 4 inset 'b', using different buffer sizes perpendicular to the valley longitudinal axis.

Altogether 17 cross-sectional profiles were made of the main Tinto-B valley and other 12 of the tributary smaller valley (Figure 5), which is west to the main valley (marked on Figure 5 right image with an arrow). The cross profiles are perpendicular to the walls of the valleys and the flow accumulation lines, what was provided by the filled DTM and the flow direction raster map. The lengths of the profiles were adjusted to the width of the valley, so they are proportional to their real width of the valley.

The average length of the cross-sectional profiles on the main valley is 2,954 metres and ranged between 3,866 and 1,200 m. The average length of the tributary valley's cross-sectional profiles is 1,177 metres and ranged between 2,162 and $519 \mathrm{~m}$ (Figure 6).
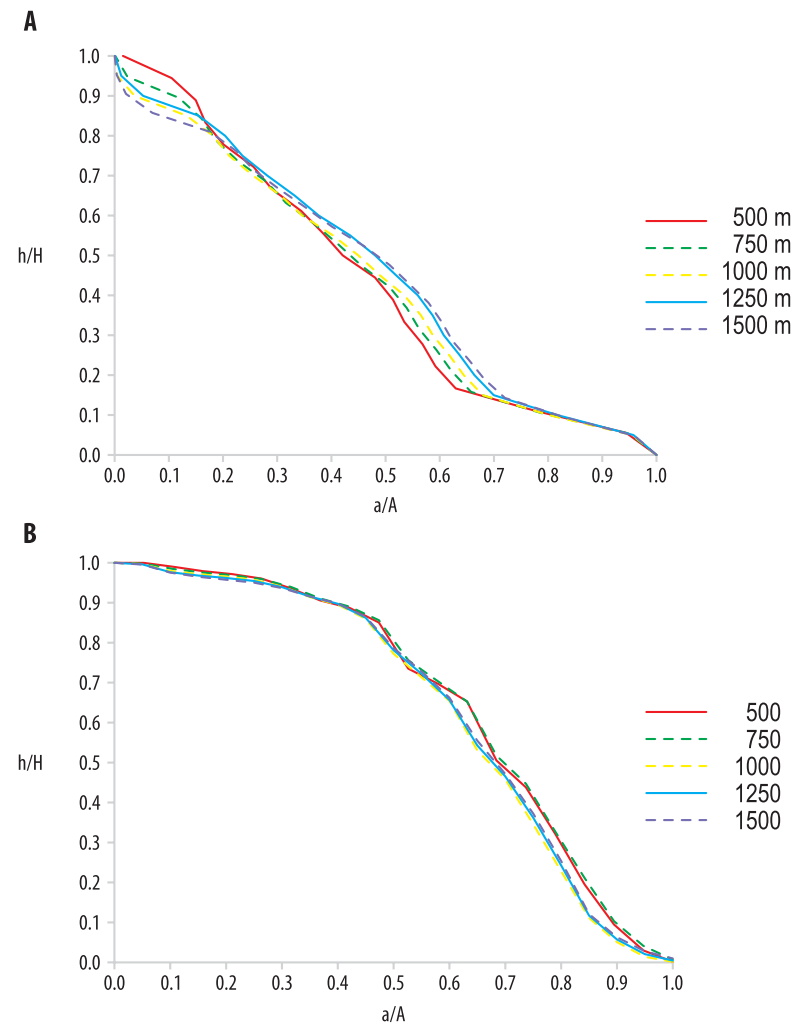

Fig. 4. Hypsographic curves in different buffer sizes (500, 750, 1,000, 1,250 and $1,500 \mathrm{~m}$ ) on the main valley (inset a), and on the biggest candidate tributary valley (inset $b$ ).

\section{Crater occurrence-based age estimation}

The first area (ID 1) shows the estimated age of the valley bottom, considering only the bedrock exposures at the end of the analysed area Tinto-B (see Figure 1). The area with ID 2 shows the neighbourhood area which is probably as old as the tributaries. ID 3 shows the sediment covered crater bottom at the South and ID 4 the sediment of the crater bottom on the North, while ID 5 the sand-covered valley bottom (Table 1, Figure 7). The minimum crater size changed between 18.6 and $35.9 \mathrm{~m}$. The biggest crater was measured in the third area (the source crater at the South) - the maximum crater size changes between 471 and 996 metres for different areas (Figure 8). 

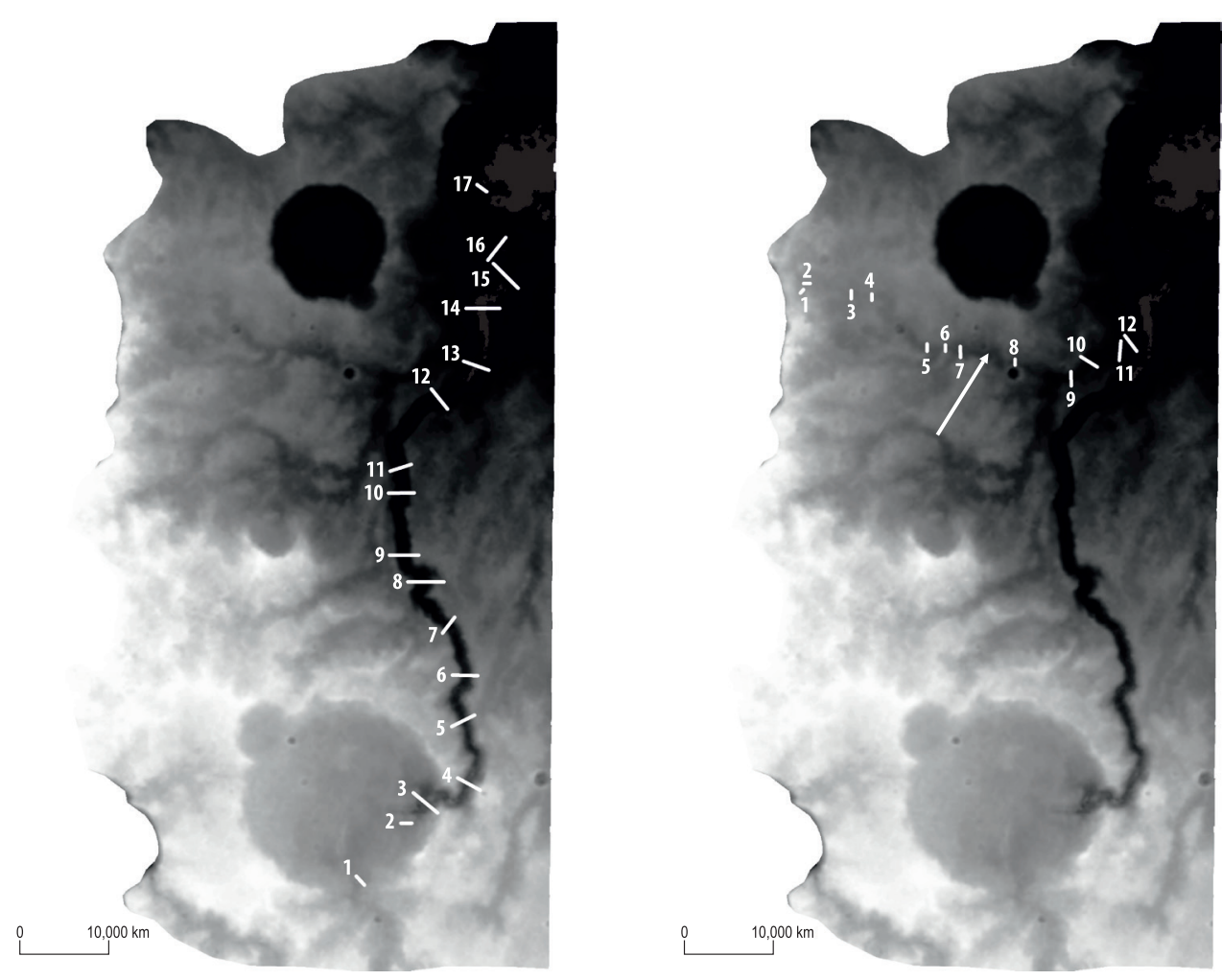

Fig. 5. Overview of the cross-sectional profiles' locations along the main (left image) and the biggest tributary valleys. The numbers show the ID of the profiles.

Table 1. Data of crater statistics

\begin{tabular}{|c|c|c|c|c|}
\hline ID & $\begin{array}{l}\text { Age, } \\
\text { Ga }\end{array}$ & $\begin{array}{c}\text { Crater size } \\
\text { range, } \mathrm{m}\end{array}$ & $\begin{array}{c}\text { Number of } \\
\text { craters }\end{array}$ & $\begin{array}{c}\text { Crater density, } \\
\text { crater } / \mathrm{km}^{2}\end{array}$ \\
\hline $\begin{array}{l}\text { 1. Bedrock exposure at valley } \\
\text { 2. Neighbourhood } \\
\text { 3. Source crater } \\
\text { 4. Terminal crater } \\
\text { 5. Dunes at valley bottom }\end{array}$ & $\begin{array}{l}2.50^{+0.8 ;-1.0} \\
3.40^{+0.1 ;-0.7} \\
3.00^{+0.4 ;-1.0} \\
2.50^{+0.6 ;-0.7} \\
0.71^{+706 ;-70}\end{array}$ & $\begin{array}{l}29-471 \\
19-730 \\
36-996 \\
19-331 \\
31-108\end{array}$ & $\begin{array}{r}66 \\
288 \\
150 \\
196 \\
5\end{array}$ & $\begin{array}{l}1.97 \\
2.31 \\
1.36 \\
5.32 \\
1.38\end{array}$ \\
\hline
\end{tabular}

\section{Results of the drainage density map}

There are several tributary valley candidates, which can be identified on topographic data but not necessarily on optical images. In Figure 9 (left inset) the main ones are indicated with red colour, which were identified by their elongated branching depressions that empty into the main Tinto-B valley.
The flow accumulation map was created from a filled DTM and flow direction map in ArcMap using GRASS GIS software. It identified such surface locations where interconnected flow pathways might have produced surface run-off.

The drainage density for grids of $1 \mathrm{~km}^{2}$ is shown in Figure 9. The highest density of the tributary sections is $29.02 \mathrm{~km} / \mathrm{km}^{2}$, and the 

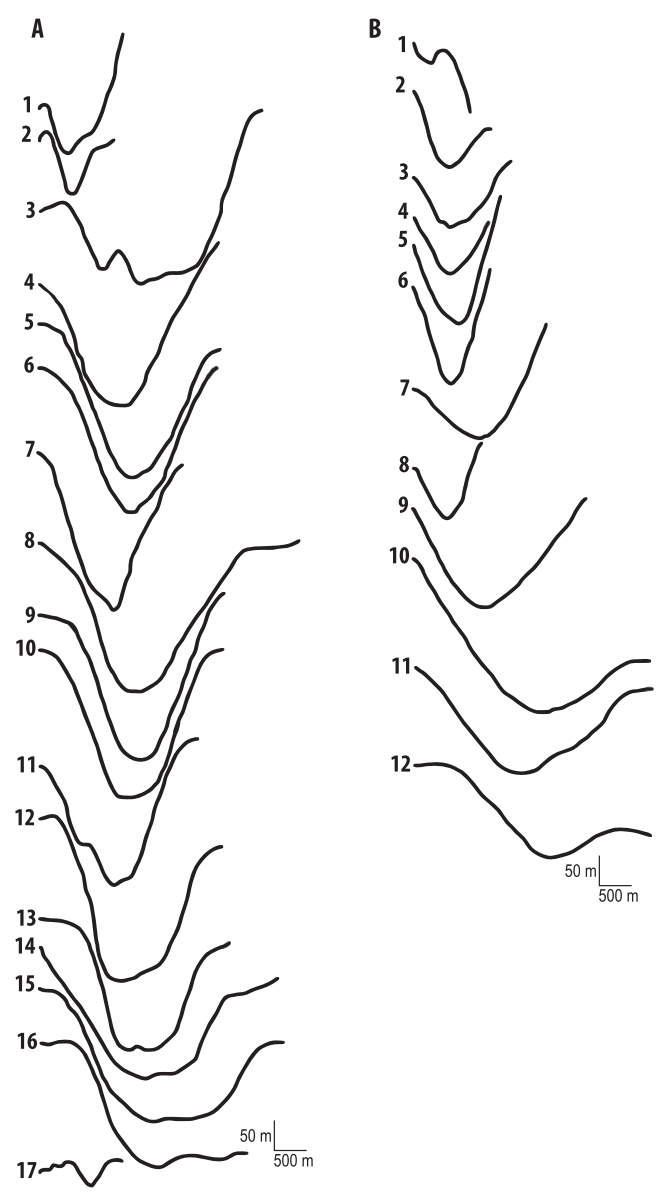

Fig. 6. Cross-sectional profiles of the analysed areas. Inset ' $a$ ' shows the main valley of Tinto-B, inset ' $b$ ' the biggest candidate tributary valley, marked by an arrow in Fig. 5 earlier.

average is $3.09 \mathrm{~km} / \mathrm{km}^{2}$. Considering only the main valley $0.017 \mathrm{~km} / \mathrm{km}^{2}$ would have been measured.

\section{Discussion}

\section{Morphological analysis}

The water carved Tinto-B might come from the source crater, here at the starting tributaries are sharp, and the valleys widen and deepen fast, possibly pointing to surface collapse and seepage like formation of this

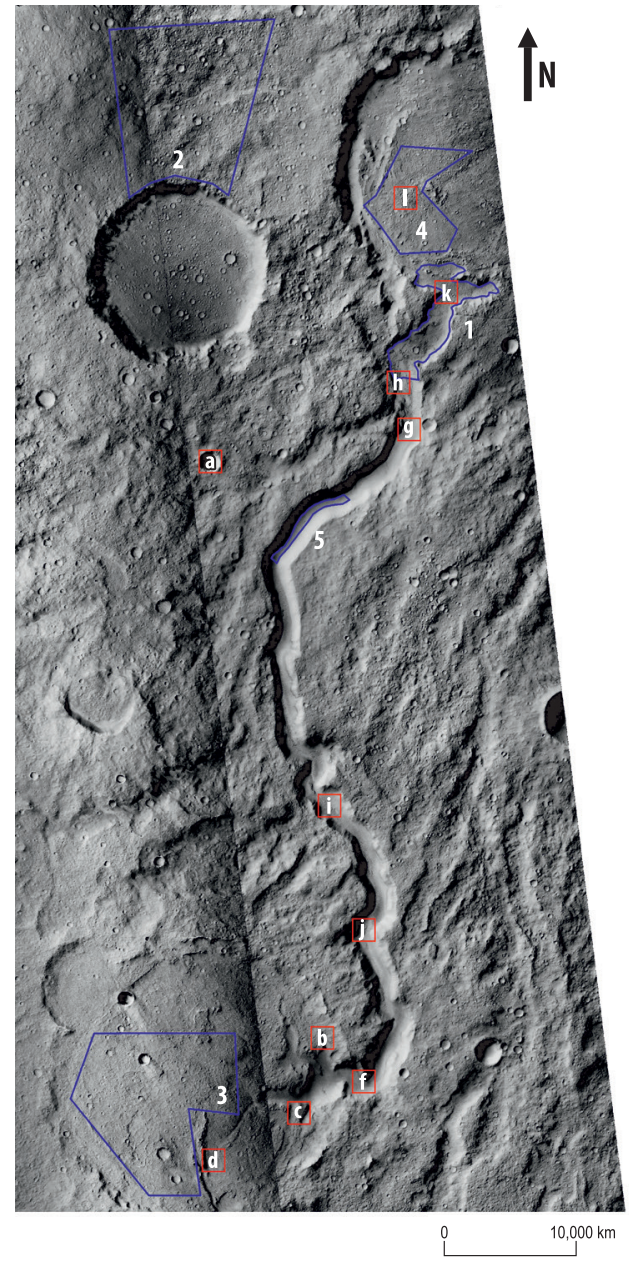

Fig. 7. Overview map of the measured areas for the crater statistics-based age estimation. The red rectangles show the locations of the images in Fig. 3. The blue rectangles show the position of the images from Fig. 3.

upper reach. This phase points to confined source water (like melted ice) accumulated in the source crater. This produced the main valley that postpones the tributaries in the surroundings. The formation of tributaries (and probably a smaller earlier valley at the location of the main valley) formed previously from an aerially distributed source.

The cross-sectional profiles (see Figure 6) show the most important morphometric changes in the valleys. The main valley can 

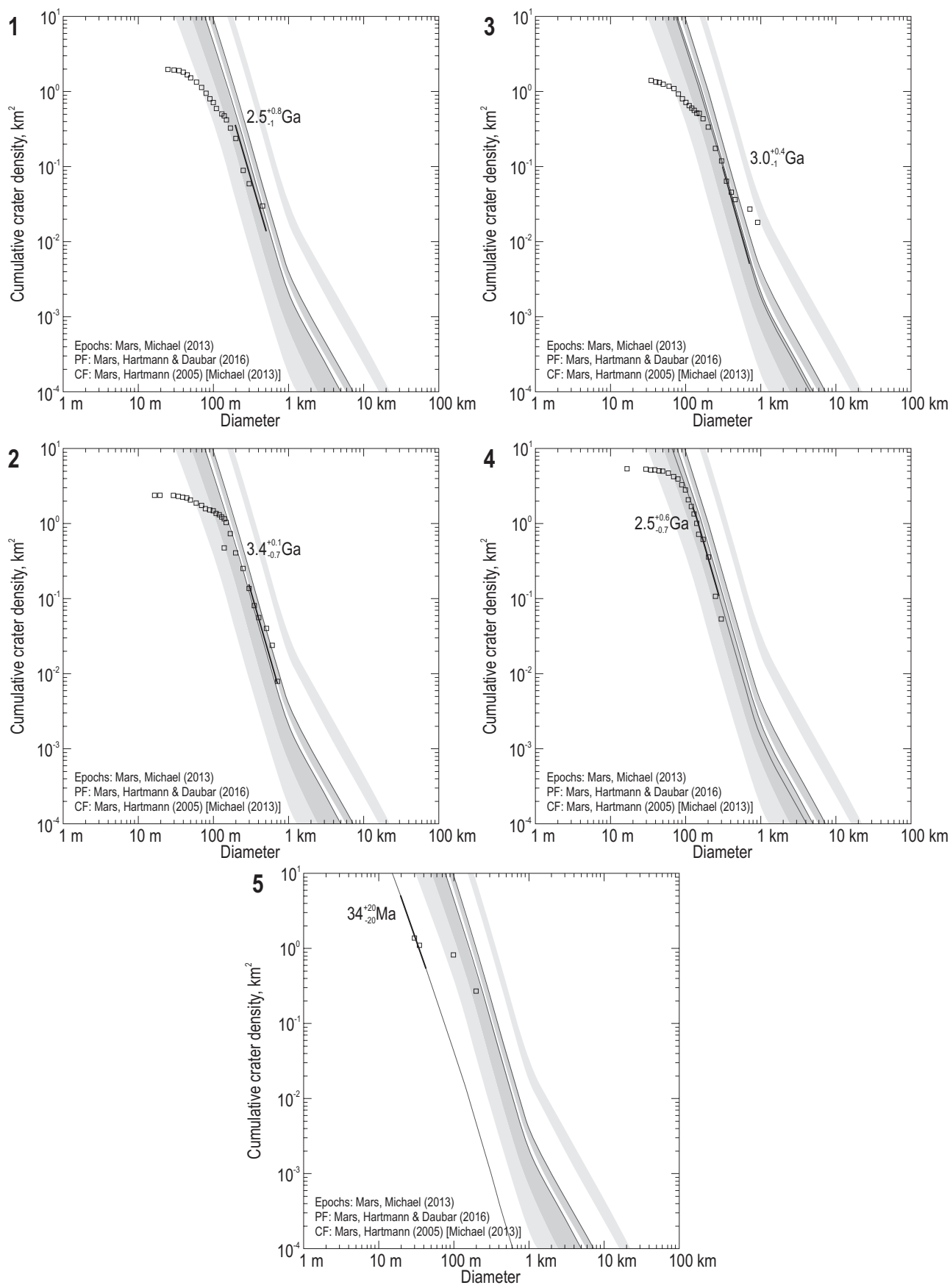

Fig. 8. Results of the crater based age estimation using the differential fit, without applying resurfacing corrections. -1 = valley bottom bedrock age; $2=$ neighbourhood; $3=$ crater on the South; $4=$ crater on the North; $5=$ sand-covered valley bottom. 

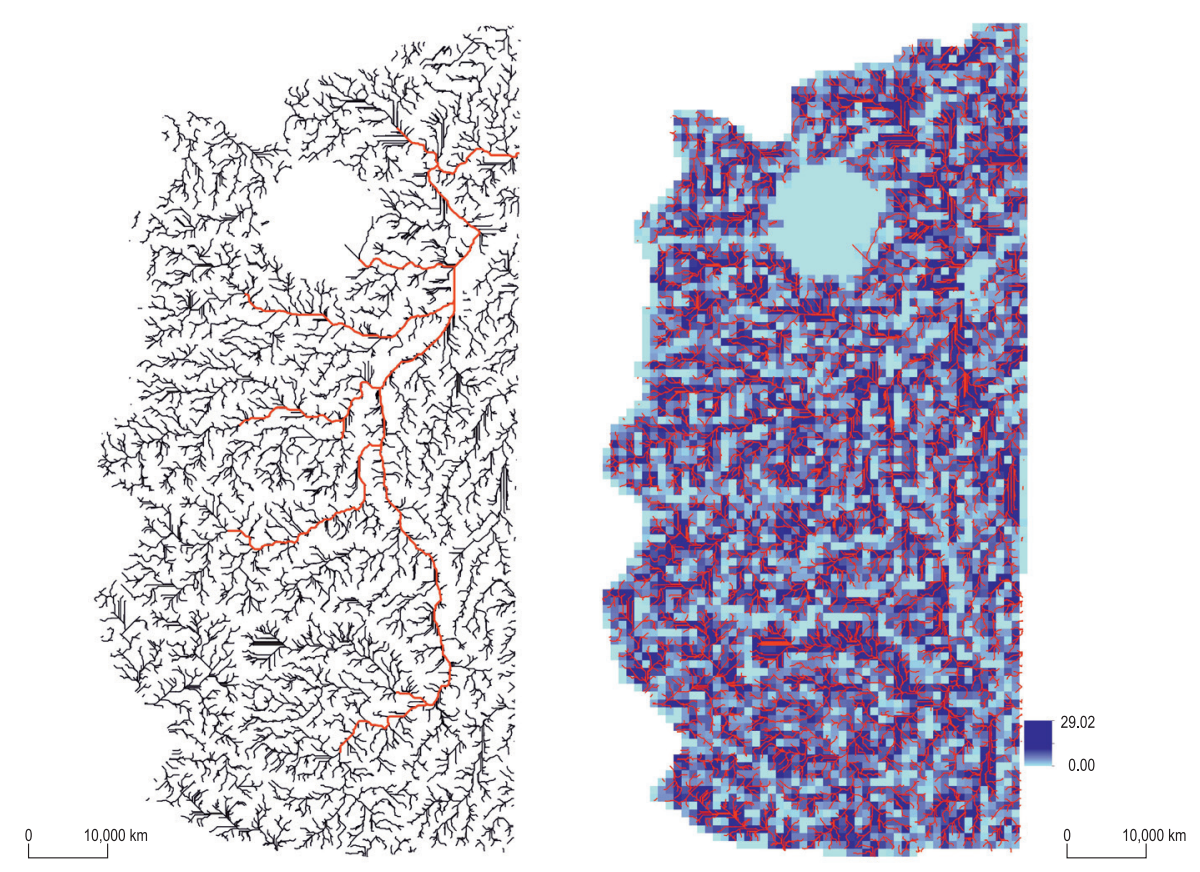

Fig. 9. The left image shows the main valley system and the supposed drainage (black lines identified automatically by ArcMap flow accumulation). The right image shows the drainage density of the analysed area in $\mathrm{km} / \mathrm{km}^{2}$. The red lines show the calculated drainage system, the left edge the watershed, while the straight right edge is artificial.

be subdivided into three different parts from the results of the cross-sectional profiles. The first section shows a " $\mathrm{V}$ " shape and steep walls (Figure 6, inset 'a'). The cross profile is in agreement with the existence of sand covered bedrock or deposit at head of the analysed valley. These elevated structures are not visible in the CTX images. The crosssectional profiles of this section did not show a direct signature of erosion forms, like landslide or debris skirt. On the Earth, this kind of valley shape usually indicates erosion dominated reaches. The hypsographic curves show a steep, eroded first (upper) section in agreement with the cross-sectional profiles. The $500 \mathrm{~m}$ buffer clearly shows this steepness and erosion, and visible on the curves of the 750 metres buffers.

The second section of the main valley is short in distance. Here the shape of the cross-profiles shows a transition between the first and the last section: from a " $\mathrm{V}$ " shape to an " $\mathrm{U}$ " shape. The hypsometric curves here indicate an accumulation dominated area (see Figure 6).

The third section of the main valley is the longest of all. The shape of the cross-sectional profiles looks like "U" shaped, the walls are steep. The valley continues in the northern crater as well. This ' $U$ ' shape of the valley is not visible in the CTX images, only on these cross-profiles. The hypsometric curves of the third section indicate an accumulation dominated area in the bottom of the valley (Figure 4 Inset ' $a$ ' - buffer $500 \mathrm{~m}$ ) but the wall of the valley is steep (Figure 4 Inset 'a' - buffer 1,000 m). The hypsometry curves in all buffer sizes show a fully accumulation filled valley bottom shape. On the wall of the main valley, there are many erosional features: downward striae pattern by mass 
movements and some slumped structures are also visible at the feet of the valley wall.

The largest tributary valley shows a different morphology, and it cannot be subdivided into different smaller sections, according to the shape of the cross-sectional profiles. The valley is heavily eroded, with rugged walls and mass movements slope.

There is only one short part in the valley where the bottom shows erosion. This erosion is visible on the 500 metres buffer, its termination part is more eroded than the upper part, which is visible on the 500 and the 750 metres buffers.

The profile types of the analysed reaches can be classified into maturity categories according to the integrated value of the integrals. In terrestrial cases, these three categories are used: Inequilibrium stage (Youth with 0.60-1.00), Equilibrium stage (Mature, 0.35 to 0.60$)$ and Monadnock phase ( $>0.35)$ (Strahler, A.N. 1952). The more eroded surfaces have a lower summarised integrated value. The main valley shows a more elevated Matury character (0.4556-0.4352), relatively to the biggest tributary that shows more Youth character $(0.6430-0.6789)$. These stages point to that while the older earlier and aerially distributed fluvial activity was not enough (in duration and total discharge) to reach a mature stage, in the case of the main valley a more mature stage was achieved by the prolonged activity or by the large discharge (what was able to transport substantial sediment).

\section{Evaluation of age estimation}

The estimated ages show some uncertainty (from the limited size of the survey area, which could not have enlarged) but are useful (see Figure 7 and Table 1). The valley bottom (ID 1) shows the estimated age of the main valley. Based on the exposed bedrock units, its $2.5 \mathrm{Ga}$ corresponds to the Late HesperianEarly Amazonian period, a moderately dry era of Mars when the liquid water was not abundant, but large outflows happened local- ly. However, it is worth to mention this age is based on a moderately small area where the probability is small for the occurrence of large craters. The age of the source crater (ID 3) and terminal crater (ID 4) are around 3.0 and $2.5 \mathrm{Ga}$, while the neighbourhood shows $3.4 \mathrm{Ga}$, which is an upper limit for the eroded tributary system around Tinto$B$. The youngest surface unit is the aeolian deposited ripples of $0.71 \mathrm{Ga}$. Considering the error bars, valley might have formed up to 3.0-3.2 Ga (except the young dunes) - this value range corresponds to Hesperian Martian age.

During this Hesperian time, the megaregolith melted at the same location in the case of the growing volcanic and tectonic activity (Rauhala, A.I. and Kostama, V.-P. 2012a). This melted megaregolith created big outflow channels, like the analysed area, Tinto-B. Another important possible source is ice accumulation and melting (CASSANELLI, J.P. and HeAD, J.W. 2016), what might occasionally happen in the Hesperian period (ScAnlON, K.E. et al. 2018). These big flood event has been represented on the hypsometric curves more precisely in the cumulated integrated values of the created buffers. The hypsometric curves of the main valley (Table 2) show an eroded valley with a ' $V$ ' shape (see Figure 6), especially on the $500 \mathrm{~m}$ buffer, which shows a deep slam into the surface.

However, the age values found in this work, including the error bars could reach up to 3.0-3.2 Ga, and these are moderately far away from the $3.7 \mathrm{Ga}$. This later value is characteristic for several similar size valleys on Mars in the Late Noachian-Early Hesperian period (FAssett, C.I. and Head, J.W. 2008). In the case using tectonic-fluvial interaction smaller networks at the Thaumaia Plateau could be dated and being around 3.7 Ga (Kereszturi, A. and Petrik, A. 2020), but multiple formation periods based on different morphologies are also suggested (BAker, V.R. 2001; Phillips, R.J. et al. 2001; Hoke, M.R.T. and Hynek, B.M. 2007). More recent activities could be observed at the flanks of some volcanoes (Ceraunius Tholus, 
Table 2. Estimated hypsometric integral values of the analysed valleys*

\begin{tabular}{r|c|c|l|l}
\hline Buffers & \multicolumn{2}{|c|}{$\begin{array}{c}\text { Integral method } \\
\text { (inset a / inset b) }\end{array}$} & \multicolumn{2}{|c}{$\begin{array}{c}\text { Possible geologic stage } \\
\text { (inset a / inset b) }\end{array}$} \\
\hline 500 & 0.4368 & 0.6659 & & \\
750 & 0.4352 & 0.6789 & & \\
1,000 & 0.4351 & 0.6430 & Equilibrium stage (Matury) & Inequilibrium stage (Youth) \\
1,250 & 0.4556 & 0.6471 & & \\
1,500 & 0.4509 & 0.6503 & & \\
\hline
\end{tabular}

*See Figure 4.

Hecates Tholus, and Alba Patera), thus, valley network formation continued until the Early Amazonian, supported by ice melting (Dickson, J.L. et al. 2009; Hobley, D.E.J. et al. 2014), and subsurface breakup of water (Berman, D.C. and Hartmann, W.K. 2002). Among the proposed two formation phases of Tinto-B (earlier eroded tributaries and later confined main valley) only the earlier activity fits with the above mentioned main fluvial period of Mars, but still being younger. The formation of the main valley happened during a later period, dominated by confined sources, here possibly from ice accumulated at the southern upper crater.

\section{Candidate tributary valleys identification}

The DTM of the analysed area shows the main valley with the other candidate tributary valleys, and this second group could not be easily visible in the DTM and could also be poorly identified in the optical images, however, using the SIMWE model, the candidate drainage system could be identified automatically using the flow accumulation map (see Figure 9). Their small size (length of sections is about few $\mathrm{km}$ ) and fragmented structure caused by later impact events prevented the identification by manual analysis but could be done using the SIMWE erosion model.

This map visible in Figure 10 is called erosion (positive value) and deposition (negative value) map, which shows the possible erosion and deposition rate in $\mathrm{kg} / \mathrm{m}^{2} \mathrm{~s}$ (the reddish colours show the erosion, the blueish colours show the accumulation).
The model shows two different types of the drainages. The first type shows the gullies, where the erosion is working during the rain event on the bottom of the small streams. The second type shows, where the accumulation is stronger than the erosion at the bottom on these small drainages, but the wall of streams are more eroded based on the appearance on the CTX images than the first type. These differences in the erosion in the two identified type gullies presume a different occurrence and origin in time. The drainages on the first type show a young surface, where the fresh sand can be eroded fast with a small amount of water or some fluid event. The walls of these drainages in the first type are declivitous. The second type of the identified small drainages are older, cut into deeper to the original terrain, in this case, the erosion dominates on the walls of these gullies instead of the bottom. These ages of the two identified drainage types come from the geomorphological analysation.

The total drainage density was calculated by the flow accumulation map and is $3.09 \mathrm{~km} / \mathrm{km}^{2}$, which is much higher than if only the main valley (identified optically) would have been considered for the same area, what gives $0.017 \mathrm{~km} / \mathrm{km}^{2}$. Comparing this value around $3.09 \mathrm{~km} / \mathrm{km}^{2}$ to other measured values from Mars, the gained results before the detailed topographic analysis gave drainage density using the well-preserved valleys for Noachian units is $0.0032 \mathrm{~km} / \mathrm{km}^{2}$, for Hesperian units $0.00047 \mathrm{~km} / \mathrm{km}^{2}$, and for Amazonian units $0.00007 \mathrm{~km} / \mathrm{km}^{2}$, excluding the volcanos where drainage densities could range up to $0.3-0.5 \mathrm{~km} / \mathrm{km}^{2}$ locally (CARR, 
A

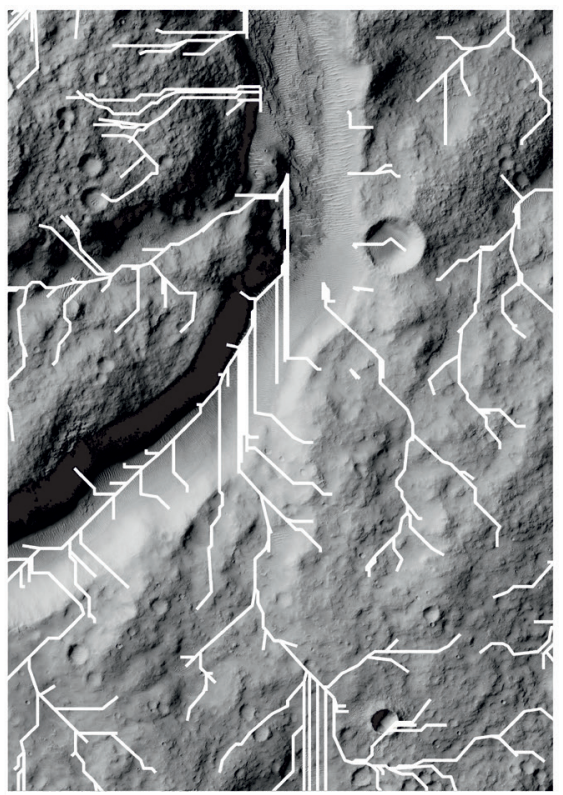

$\stackrel{0}{c}$

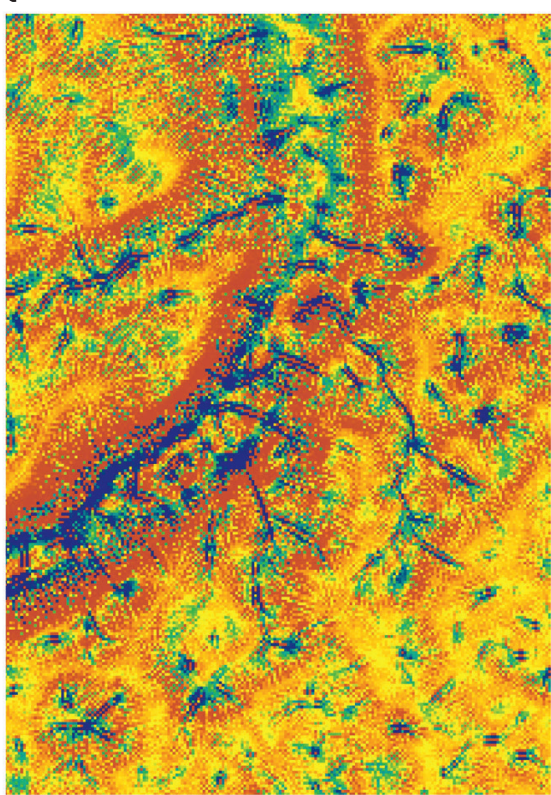

$1,500 \mathrm{~m}$

$\mathbf{E}_{-0.016}^{0.018}$

B
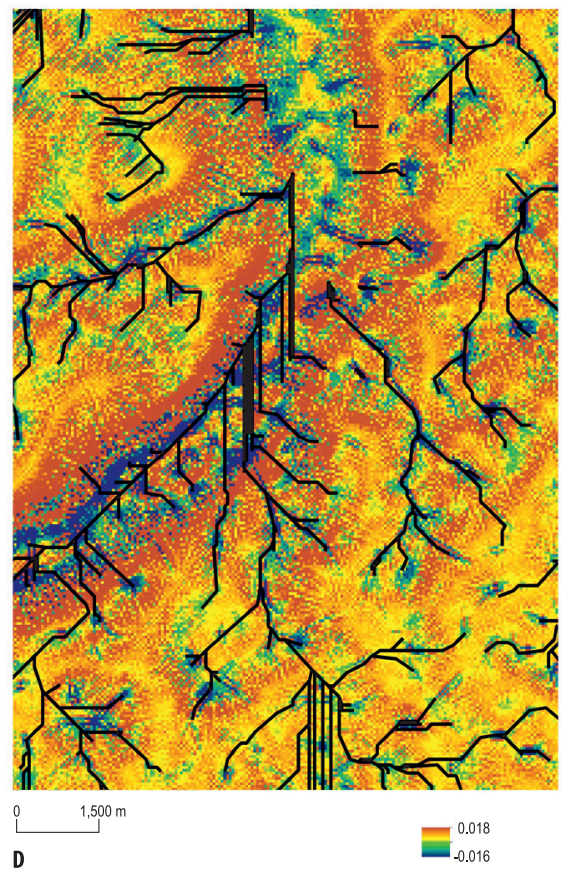

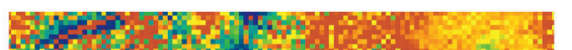

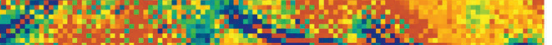

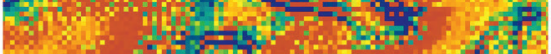

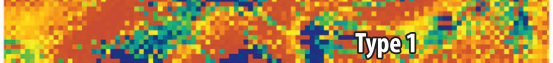

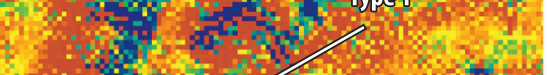
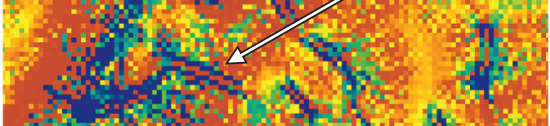

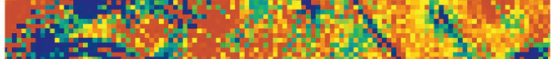

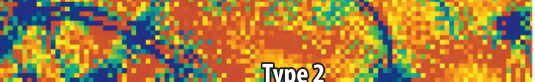

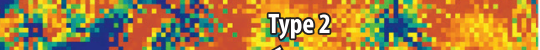

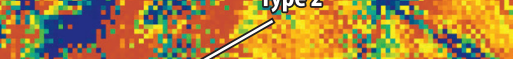

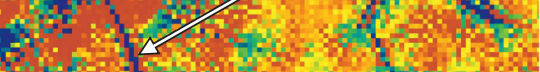

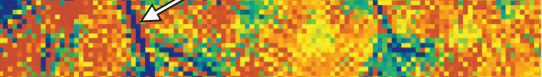

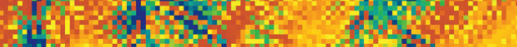

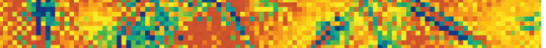
B.

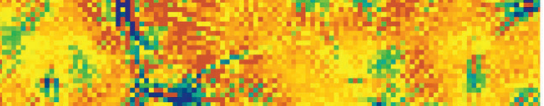

$750 \mathrm{~m}$

$=-0.018$

Fig. 10. Comparison between drainage map, what was generated from the flow accumulation (a) and the SIMWE erosion model (b, $c$ and $d$ ). The positive value on insets ' $b$ ' to ' $d$ ' show the erosion. Inset ' $d$ ' shows two different types of small drainage what were identified by the model. 
M.H. and Chuang, F.C. 1997). However, topographic data based valley reconstruction gave much higher drainage density: according to the analysis of STEPINSKI, T.F. and Collier, M.L. (2003) using MOLA data could reach $0.10-0.01$ at certain locations on Mars. Craddock, R.A. et al. (2001) also suggested about 20 times higher drainage density than previous estimations, and Hyneck, B.M. and Phillips, R.J. (2003) also found values around $0.20-0.06$. However, our values are even higher, possibly because the sophisticated flow accumulation map is more sensitive than others used earlier. Although it is possible that this value is not realistically too high, but its further analysis could be the target of future work.

\section{Conclusions}

A fluvial valley was analysed close to the Martian equator (2 ${ }^{\circ} 55^{\prime}$ South and $111^{\circ} 53^{\prime}$ East) near to Palos crater and Tinto Vallis, named Tinto-B, surrounded by several smaller but heavily eroded tributary valleys.

The age estimation was made in 4 main terrain types. The source and terminal sink craters, as well as the bedrock outcrop at the bottom of the main valley showed age values ranging between 3.0-2.5 Ga, around Late and Early Hesperian. Although substantial uncertainty exists here, this period is characterised by rare but large floods events, and suggesting Tinto-B formed much later than most of the other precipitation or surface ice melting fed (not outflow category) valleys on Mars. Considering the possible tributaries in the neighbouring terrain, they might have formed earlier than the main valley, around the same period as many of the other Martian valleys.

The main valley can be subdivided in three different sections with transitions based on the shape of their cross-sectional profiles and hypsometric curves. The first section of the main valley has a ' $\mathrm{V}$ ' shape with steep valley walls with a small number of erosional forms it, which may have been formed a huge amount of water. The second section is a transition style with more ' $U$ ' shaped with steep valley walls and landforms associated with mass-wasting processes.

The hypsometric curves were created in different buffer widths, which point to the maturity of the fluvial system. The cumulated integrated values of the main valley point to an equilibrium (mature) stage, but the biggest tributary valley has higher cumulated integrated values, which point to a youth stage.

The SIMWE model used to identify the small scale erosion landforms and estimate the possible origin points of the mass movements, which are not visible on the DTM or in the images. This was the first time to test this model in the Martian environment. The results of the model show that the average drainage density of $3.09 \mathrm{~km} / \mathrm{km}^{2}$ being much higher than based on only the optical images and other works - suggesting further evaluation of drainage density is required on Mars as it might be substantially larger than previously suggested.

Acknowledgement: The impact craters based age estimation was supported by the GINOP-2.3.2-15-2016-00003.

\section{REFERENCES}

BAKer, V.R. 1988. The channels of Mars. The NASA Mars Conference Proceedings (A89-16176 04-91). San Diego, California, Univelt Inc., 75-90.

Baker, V.R., Carr, M.H., Gulick, V.C., Williams, C.R. and Marley, M.S. 1992. Channels and valley networks. The NASA Mars Conference Proceedings (A93-27852 09-91). San Diego, California, Univelt Inc., 493-522.

BAKER, V.R. 2001. Water and the Martian landscape. Nature 412. 228-236.

Berman, D.C. and Hartmann, W.K. 2002. Recent fluvial, volcanic, and tectonic activity on the Cerberus Plains of Mars. Icarus 159. 1-17.

CArr, M.H. 1981. The Surface of Mars. New Haven, London, Yale University Press.

CArr, M.H. and Chuang, F.C. 1997. Martian drainage densities. Journal of Geophysical Research 102(E4), 9145-9152.

CARr, M.H. and MALIN, M.C. 2000. Meter-scale characteristic of Martian channels and valleys. Icarus 146. 366-386. 
Cassanelli, J.P. and Head, J.W. 2016. Lava heating and loading of ice sheets on early Mars: Predictions for meltwater generation, groundwater recharge, and resulting landforms. Icarus 271. 237-264.

Clifford, S.M. 1993. A model for the hydrologic and climatic behaviour of water on Mars. Journal of Geophysical Research 98(E6), 10973. Doi: 10.1029/93je00225

Conway, S., Pommerol, A., Thomas, N., RaAck, J., Phillipe, M. and Cremonese, G. 2019. Seasonal ices and gullies on Mars studied with CaSSIS. EPSC-DPS Joint Meeting, 15-20 September 2019 in Geneva, Switzerland, Id. EPSC-DPS2019-1810

Craddock, R.A., Irwin, R.P. and Howard, A.D. 2001. Martian drainage densities: analyses from MOLA digital elevation models. Workshop on the Martian Highlands and Mojave Desert Analogs, 20-27 October, 2001. Las Vegas, Nevada, Abstract 4016.

Craddock, R.A. and Howard, A.D. 2002. The case for rainfall on a warm, wet early Mars. Journal of Geophysical Research 107. (E11), 5111. Available at https://doi.org/10.1029/2001JE001505

De Haas, T., McArdell, B.W., Conway, S.J., McElwaine, J.N., Kleinhans, M.G., Salese, F. and Grindrod, P.M. 2019. Initiation and flow conditions of contemporary flows in Martian gullies. Journal of Geophysical Research 124. (8): 2246-2271.

Dickson, J.L., Fassett, C.I. and Head, J.W. 2009. Amazonian-aged fluvial valley systems in a climatic microenvironment on Mars: Melting of ice deposits on the interior of Lyot Crater. Geophysical Research Letters 36. Cite ID L08201.

Dohm, J.M., Hare, T.M., Robbins, S.J., Williams, J.-P., Soare, R.J., El-Maarry, M.R., Conway, S.J., BuczKowski, D.L., Kargel, J.S., BANKS, M.E., Fairén, A.G., Schulze-Makuch, D., Komatsu, G., Miyamoto, H., Anderson, R.C., Davila, A.F., Mahaney, W.C., Fink, W., Cleaves, H.J., Yan, J., HyneK, B. and Maruyama, S. 2015. Geological and hydrological histories of the Argyre province, Mars. Icarus 253. 66-98.

Fassett, C.I. and Head, J.W. 2008. The timing of Martian valley network activity: Constraints from buffered crater counting. Icarus 195. 61-89.

Goldspiel, J.M. and Seurres, S.W. 2000. Groundwater sapping and valley formation on Mars. Icarus 148. 176-192.

Grant, J.A. 2000. Valley formation in Margaritifer Sinus, Mars, by precipitation recharged groundwater sapping. Geology 28. 223-226.

Hargitai, H. and Kereszturi, A. (eds.) 2015. Encyclopaedia of Planetary Landforms. Springer Reference. New York, Springer. Available at https:// doi.org/10.1007/978-1-4614-3134-3

Hargitai, H.I., Gulick, V.C. and Glines, N.H. 2019. Evolution of the Navua Valles region: Implications for Mars' paleoclimatic history. Icarus 330. 91-102.
Hauber, E., Gwinner, K., Kleinhans, M., Reiss, D., Di Achille, G., Ori, G.-G., Scholten, F., Marinangeli, L., Jaumann, R. and Neukum, G. 2009. Sedimentary deposits in Xanthe Terra: Implications for the ancient climate on Mars. Planetary and Space Science 57. (8-9): 944-957.

Hobley, D.E.J., Howard, A.D. and Moore, M. 2014. Fresh shallow valleys in the Martian valley: Evidence from Newton and Gorgnim basins. Journal of Geophysical Research 116. 128-153.

Hoкe, M.R.T. and Нyneк, B.M. 2008. Analysing and dating valley networks in Arabia Terra and Terra Meridiani, Mars. 39 $9^{\text {th }}$ Lunar and Planetary Science Conference, 10-14 March 2008. League City, Texas, LPI Contribution No. 1391. Abstract 2183.

Horne, D.J. 2018. Young, small-scale surface features in Meridiani Planum, Mars: A possible signature of recent transient liquid and gas emissions. Planetary and Space Science 157. 10-21.

Howard, A.D., Moore, J.M. and Irwin, R.P. 2005. An intense terminal epoch of widespread fluvial activity on early Mars: 1 . Valley network incision and associated deposits. Journal of Geophysical Research 110. (E12) Cite ID E12S14.

Hyneck, B.M. and Phillips, R.J. 2003. New data reveal, integrated drainage systems on Mars indicative of past precipitation. Geology 31. 757-760.

HүNeK, B.M., ВеАсн, M. and Ноке, M.R.T. 2010. Updated global map of Martian valley networks and implications for climate and hydrologic processes. Journal of Geophysical Research 115. (E9) Cite ID E09008.

Irwin, R.P. and Howard, A.D. 2002. Drainage basin evolution in Noachian Terra Cimmeria. Mars. Journal of Geophysical Research 107. (E7) JE001818.

Kereszturi, A. and Petrik, A. 2020. Age determination for valley networks on Mars using tectonic-fluvial interaction. Planetary and Space Science 180. Article id. 104754. Doi: 10.1016/j.pss.2019.104754

Kneissl, T., Gasselt, S.V. and Neukum, G. 2011. Mapprojection-independent crater size-frequency determination in GIS environments - New software tool for ArcGIS. Planetary and Space Science 59. (11-12): 1243-1254. Doi: 10.1016/j.pss.2010.03.015

Mangold, N., Quantin, C., Ansan, V., Delacourt, C. and Allemand, P. 2004. Evidence for precipitation on Mars from Dendritic Valleys in the Valles Marineris area. Science 305. 78-81.

Martín-Torres, F.J., Zorzano, M.-P., ValentínSerrano, P., Harri, A.-M., Genzer, M., Kemprinen, O., Rivera-Valentin, E.G., Jun, I., Wray, J., Madsen, B.M., Goetz, W., McEwen, A.S., Hardgrove, C., Renno, N., Chevrier, V.F., Mischna, M., NavarroGonzález, R., Martínez-Frías, J., Conrad, P., McConnochie, T., Cockell, Ch., Berger, G., Vasavada, A.R., Sumner, D. and Vaniman, D. 2015. Transient liquid water and water activity at Gale Crater on Mars. Nature Geoscience 8. (5): 357-361. 
Michael, G. and Neukum, G. 2010. Planetary surface dating from crater size- frequency distribution measurements: Partial resurfacing events and statistical age uncertainty. Earth and Planetary Science Letters 294. (3-4): 223-229. Doi: 10.1016/j. epsl.2009.12.041

MiLton, D.J. 1973. Water and processes of degradation in the Martitan landscape. Journal of Geophysical Research 78. 4037-4047.

Mitasova, H., Thaxton, C., Hofierka, J., Mclaughlin, R., Moore, A. and Mitas, L. 2004. Path sampling method for modelling overland water flow, sediment transport, and short term terrain evolution in Open Source GIS. Computational Methods in Water Resources 2. Proceedings of the $15^{\text {th }}$ International Conference on Computational Methods in Water Resources Developments in Water Science, Chapel Hill, North Carolina, 13-17 June 2004. 1479-1490. Doi: 10.1016/s0167-5648(04)80159-x

Möhlmann, D. and Kereszturi, A. 2010. Viscous liquid film flow on dune slopes of Mars. Icarus 207. (2): 654-658. Doi: 10.1016/j.icarus.2010.01.002

Neukum, G., Jaumann, R. and the HRSC CoInvestigator Team 2004. High resolution stereo camera of Mars Express. In Mars Express: The Scientific Payload. Ed.: Wilson, A., Berlin, DLR, 15-74.

PAL, B. 2019. Global distribution of near-surface relative humidity levels on Mars. $50^{\text {th }}$ Lunar and Planetary Science Conference. 21-24. March 2019. The Woodlands, Texas, LPI Contribution No. 2132. Id.1831.

Palumbo, A.M., Head, J.W. and Wilson, L. 2020. Rainfall on Noachian Mars: Nature, timing, and influence on geologic processes and climate history. Icarus 347. Article id. 113782.

Phillips, R.J., Zuber, M.T., Solomon, S.C., Golombek, M.P., JAKoskY, B.M., BANERDT, W.B., SMITH, D.E., Williams, R.M., Hynek, B.M., Aharonson, O. and HAUCK, S.A. 2001. Ancient geodynamics and globalscale hydrology on Mars. Science 291. 2587-2591.

Rauhala, A.I. and Kostama, V.-P. 2012a. Origins and age constraints of the Palos Crater floor deposits and Tinto Vallis, Mars. $43^{\text {rd }}$ Lunar and Planetary Science Conference, 19-23. March 2012. The Woodlands, Texas, LPI Contribution No. 1719. Abstract 2261.
Rauhala, A.I. and Kostama, V.-P. 2012b. Palos crater and Tinto Vallis, Mars: Analysis of proposed fluvial and volcanic scenarios. European Planetary Science Congress, IFEMA-Feria de Madrid, 23-28 September 2012, Madrid, Spain, EPSC. Abstracts, Vol. 7. EPSC2012-444.

Salese, F., McMahon, W.J., Balme, M.R., Ansan, V., Davis, J.M. and Kleinhans, M.G. 2020. Sustained fluvial deposition recorded in Mars' Noachian stratigraphic record. Nature Communications 11. Article id. 2067.

Scanlon, K.E., Head, J.W., Fastook, J.L. and Wordsworth, R.D. 2018. The Dorsa Argentea Formation and the Noachian-Hesperian climate transition. Icarus 299. 339-363.

Schorghofer, N., Levy, J. and Goudge, T.A. 2018. Seasonal frost as source of liquid water on Mars. $49^{\text {th }}$ Lunar and Planetary Science Conference, 19-23. March 2018. The Woodlands, Texas, LPI Contribution No. 2083. Abstract P53F-3024.

Sidiropoulos, P. and Muller, J. 2015. On the status of orbital high-resolution repeat imaging of Mars for the observation of dynamic surface processes. Planetary and Space Science 117. 207-222. Doi: 10.1016/j.pss.2015.06.017

Stepinski, T.F. and Collier, M.L. 2003. Drainage densities of computationally extracted Martian drainage basins. Sixth International Conference on Mars, 20-25 July 2003, Pasadena, California, Abstract 3100.

Strahler, A.N. 1952. Hypsometric (area-altitude) analysis of erosional topography. Geological Society of America Bulletin 63. (11): 1117-1142. Doi: 10.1130/0016-7606(1952)63[1117:haaoet]2.0.co;2

Vaz, D.A., Di Achille, G., Hynek, B.M., Nelson, W. and Williams, R.M.E. 2020. Martian fan deposits: Insights on depositional processes and origin from mass balance survey. Earth and Planetary Science Letters 533. Article id. 116049. 